\title{
PENGGUNAAN APLIKASI ZOOM CLOUD MEETING PADA PROSES PEMBELAJARAN ONLINE SEBAGAI SOLUSI DI MASA PANDEMI COVID 19
}

Fitriyani, Marisa Deza Febriyeni, dan Nurlila Kamsi

Dosen dan Mahasiswa Sekolah Tinggi Agama Islam Bumi Silampari Lubuklinggau

fitriyani@staibsllg.ac.id,marisadeza1212@gmail.com, dan nurlilakamsi@gmail.com

\begin{tabular}{ll}
\hline Abstrak & This article depicts a slightly \\
\hline Article History & different educational pattern due \\
Received :10 Juli 2020 & to the outbreak of the disease, \\
Revised :12 Juli 2020 & which came into Indonesia since \\
Accepted :15 Juli 2020 & the beginning of last March. \\
\hline Keywords : & Impact on the whole order in \\
Covid 19, Zoom Cloud & Indonesia, such as economic, \\
Meeting, Online Learning & political, social, and even impact \\
Barriers & the education system. Since the \\
& circular letter issued by the \\
& government that all \\
& students/students to do distance \\
& learning and by using via online. \\
& So between teachers and students \\
& need a bridge to keep learning \\
& active even in the middle of \\
& pandemic. A cloud meeting's zoom \\
& application, as if to be a new class \\
& in the learning process and the \\
& application also becomes a \\
& solution for learning at school to \\
& run properly. Despite the many \\
& students who complained about \\
this online learning. But this & pattern of modern education \\
& should still be implemented until \\
& the return state is conducive.
\end{tabular}




\section{Pendahuluan}

Akhir tahun 2019, perhatian dunia tertuju pada satu kota di China yang bernama Wuhan, dengan kemunculan virus yang bernama Corona Virus Disease atau yang sering disebut covid. Karena kemunculannya pada tahun 2019, maka virus ini dinamakan covid 19. Dr. Erlina Burhan selaku satgas waspada dan niaga NICOV PB IDI mengatakan bahwa virus ini berkembang didalam tubuh hewan seperti di kelelawar, musang, kucing, ular, onta dan mamalia lainnya. 29 pasien pertama yang dirawat sebagian besar bekerja di fish market (pasar ikan), namun yang perlu kita ingat bahwa virus corona tidak hidup di aquatic animal (hewan air).Dan dipasar tradisional ini jga dijual dengan berserakan, binatangnya ada ular, kelelawar, babi, musang dan lain-lain. Virus ini sangat cepat sekali menular, sampai pada awal januari akses kota Wuhan ditutup total.

Dalam hitungan hari virus ini sangat cepat sekali menyebar ke beberapa negara didunia, seperti Jerman, Thailand, hingga virus ini sampai ke negara Indonesia. "Presiden Indonesia Joko Widodo mengambil langkah pengendalian penyebaran covid 19 yang dinilai ahli kesehatan dianggap lambat." (Zahrotunnimah : 2020). Menetapkan penyebaran covid 19 diwilayahnya dengan berkonsultasi pada Badan Nasional Penanggulangan Bencana (BNPB).Dan pernyataan presiden menyusul bahwa Indonesia terpapar covid 19 sebagai bencana non alam yang semakin meningkat setiap harinya.

Hal ini membuat pemerintah bergerak cepat dalam penanggulangan virus corona 19 ini dengan tim para medis sebagai garda terdepan. Dengan himbauan kepada masyarakat untuk tetap didalam rumah, menggunakan masker, jaga kebersihan, social distancing. Hingga pemerintah pun memberlakukan Pembatasan sosial berskala besar (PSBB) pada awal april lalu. Tentu saja dengan adanya virus ini berdampak pada beberapa sistem yang ada di Indonesia seperti sistem ekonomi, politik, keagamaan, sosial serta berdampak pada sistem pendidikan. Dan mengubah kebijakankebijakan pendidikan (Firman dan Sari Rahayu Rahman : 2020), "salah satunya melalui surat edaran Kementrian Pendidikan dan Kebudayaan (Kemendikbud) Direktorat Pendidikan Tinggi No. 1 Tahun 2020 tentang pencegahan covid 19. Didalam surat tersebut dimuat 10 poin yang salah satunya himbauan kepada seluruh jenjang pendidikan untuk melakukan pembelajaran jarak jauh (daring) dan belajar dirumah masing-masing." Himbauan ini ditanggap secara 
sigap oleh setiap lembaga pendidikan untuk meliburkan mahasiswa atau siswa untuk belajar dirumah namun dipindahkan belajar via online dirumah masing-masing.

Himbauan ini mengubah wajah pendidikan yang selama ini proses pembelajaran dilakukan secara tatap muka, namun untuk memutus mata rantai corona pembelajaran ini pun dilakukan secara online. Berbicara mengenai pembelajaran media online, membuat anak-anak tak terlepas dari gadget nya.Hingga sebagian waktunya dihabiskan untuk gadget nya.Dan pembelajaran online ini membutuhkan aplikasi sebagai jembatan antara guru/dosen dengan siswa/mahasiswa. Seperti Aplikasi whatsapp, google classroom, skype, zoom cloud meeting dan aplikasi lainnya yang mendukung.

Tulisan ini terfokus pada pembelajaran online yang menggunakan aplikasi zoom cloud meeting yang lebih dominan digunakan siswa/mahasiswa kelas tinggi dalam pembelajaran online dan secara tatap muka walau dari kejauhan. "Sabran Sabara (Zainal Abidin : 2020) menyatakan zoom cloud meeting menjadi media pembelajaran yang cukup efektif dengan kecenderungan 77,27 \%. Hasil serupa didapatkan oleh Sari mengngkapkan ada pengaruh signifikan terhadap kemudahan, kemanfaatan dan layanan aplikasi zoom cloud meeting ini."

Dari penelitian ini menjelaskan kelebihan aplikasi zoom cloud meeting yang marak digunakan pada kaum intelektual untuk proses pembelajaran, rapat ataupun seminar online. Aplikasinya pun fleksibel dan sangat mudah digunakan dan didapat. Selain dari kelebihan, aplikasi ini juga terdapat kekurangan yang tak jarang banyak siswa/mahasiswa mengeluhkan belajar menggunakan aplikasi ini, yang akan kita bahas lebih lanjut pada halaman selanjutnya.

Selama wabah covid 19 ini masih berlangsung di Indonesia, kemungkinan kecil untuk dapat belajar kembali secara tatap muka dikelas. Pembelajaran via online menjadi solusi atas keberlangsungan proses pembelajaran agar tetap dilakukan meski kurang efektif, agar materi pelajaran tetap sampai kepada siswa/mahasiswa.

\section{Metode Penelitian}

Metode yang digunakan dalam kajian ini menggunakan metode atau pendekatan kepustakaan (library research). Penelitian ini ditulis berdasarkan hasil kajian terhadap bahan pustaka yang relevan, baik berupa buku, jurnal, artikel dan lain sebagainya yang terkait dengan 
fokus masalah diatas. Data yang dikumpulkan dalam penelitian ini adalah data kualitatif yang bersifat tekstual yakni berupa pandangan dan pemikiran yang berada dalam bahan pustaka yang dimaksud.

Sejalan dengan metode yang dipakai, maka teknik pengumpulan data yang tepat digunakan untuk penelitian ini adalah teknik dokumenter artinya data dikumpulkan melalui dokumendokumen seperti yang dimaksud sebagai bahan pustaka.

\section{Corona Virus Disease 19}

Penghujung tahun 2019, dunia digemparkan dengan kemunculan virus jenis baru yang bernama corona virus disease 2019 atau yang lebih akrab disebut sebagai covid 19.Virus ini masih satu keluarga dengan virus SARS dan MERS, namun virus ini lebih parah, dimulai dengan gejala flu hingga infeksi pernafasan yang cukup parah.(Walsyukurniat Zendrato : 2020)"Menurut WHO (World Health Organization). Virus ini bersifat zoonosis artinya penyakit ini dapat ditularkan antara hewan dan manusia seperti rabies dan malaria." Dengan ditandai dengan gejala flu ringan, seperti batuk dan bersinbersin, demam tinggi, infeksi saluran pernafasan.Jika ini berkepanjangan maka dapat menyebabkan kematian. Masa inkubasi dari virus ini pun sangat cepat, hingga virus ini harus mendapatkan bantuan para medis dengan sangat sigap.

Berdasarkan data yang diperoleh dari South Morning China, kass pertama virus corona ditemukan pada seseorang yang berusia 55 tahun, yang berasal dari Hubei, china. Orang ini pertama yang terjangkiti virus corona tercatat setelah kasus pertama, dilaporkan muncul 5 kasus baru hingga 15 desember corona virus di china meningkat menjadi 27 orang (Walsyukurniat Zendrato : 2020),

Penyebaran virus ini begitu cepat menular dari manusia satu ke manusia lain. Dan virus ini masuk kedalam tubuh manusia melalui saluran pernapasan. Menyebarnya virus ini dikenal dengan nama lain contagion theory yang mengacu dengan cara yang cepat dan spesifikasi. "Istilah ini pertama kali digunakan oleh Giralamo Frascator oada tahun 1546 yang menulis gagasan tentang infeksi. Kini istilah contagion penggunaannya tidak terbatas penyakit, tetapi juga sebagai metafora untuk sesuatu yang menyebar dengan cepat dari orang ke orang (Nailul Mona : 2020)." Serupa dengan teori ini, 
virus corona pun tersebar dengan cara yang cepat dan tanpa memandang batas usia, suku ataupun ras. Melalui jaringan sosial yang membuat seseorang terhubung langsung dengan orang lain yang terpapar virus ataupun tidak. Masuknya virus ini melalui droplet, artinya menyebar menyebar melalui percikan air yang keluar dari dalam tubuh seperti batuk atau bersin (Nur Rohim Yunus dan Annisa Rezki : 2020)." Sehingga pencegahan dari droplet ini hanya dapat dilakukan dengan menggunakan masker apabila sedang berada diluar rumah, serta social distancing (jaga jarak) minimal 1 meter dengan orang lain sebagai wujud dari pencegahan droplet ini.

Tak hanya dinegara lain yang dihebohkan dengan virus ini, di Indonesia pun mengalami hal demikian. Pada awal maret lalu, "dilansir dari CNN Indonesia Nasional, Presiden Republik Indonesia Joko Widodo menyebut ada dua orang warga negara Indonesia (WNI) asal Jepang yang positif virus corona. Ada orang Jepang yang ke Indonesia, kemudia tinggal di Malaysia, di cek disana ternyata positif corona. Tim Indonesia langsung menelusuri, kata dia di Jakarta (2/3) (CNN Indonesia Nasional : 2020). Sejak pemberitahuan ini tersebar luas, membuat masyarakat Indonesia menjadi panik dengan kedatangan virus ini.Corona bagaikan tamu yang tak diundang, hingga masyarakat Indonesia belum siap menghadapinya. Namun itu lah faktanya. Kita harus siap dalam melawan virus ini.

Pemerintah pun menghimbau masyarakat untuk tetap berada didalam rumah. Jikapun keluar rumah maka harus mengenakan APD (Alat Pelindung Diri) seperti masker, selalu jaga kebersihan, mencuci tangan, social distancing, dan phsycal distancing. Selain dihimbau untuk lockdown (tetap dirumah) pemerintah pun memberlakukan Pembatasan Sosial Berskala Besar, seperti kebijakan yang dikeluarkan pemerintah Indonesia untuk membatasi kegiatan pergerakan orang untuk memperlambat laju penularan virus corona (Arianto Patunru: 2020). Dengan adanya PSBB ini, membatasi pergerakan masyarakat dan barang. Artinya menutup akses yang bisa mengundang kerumunan orang banyak. Serta menutup akses transportasi tujuan luar kota seperti kereta api, Bandara dan jalur laut. Untuk mencegah kedatangan dari luar kota, dan patroli ketat dari petugas keamanan untuk mencegah kerumunan yang terjadi.

Tak hanya pemberlakuan PSBB saja, corona virus ini pun berdampak kepada sistem tatanan ekonomi, politik, sosial serta pendidikan. Tulisan ini lebih merujuk kepada sistem pendidikan, 
maka akan dibahas lebih lanjut pada halaman selanjutnya. Tentu ada hikmah dari setiap cobaan yang datang. Allah Subhanahu wa Ta`ala menciptakan virus ini tentu ada hikmah yang harus kita ambil. Sebab Allah Subhanahu wa Ta ala berfirman (Dapertemen Agama Republik Indonesia: 2009) dalam surat Al-Baqarah ayat 155-156.

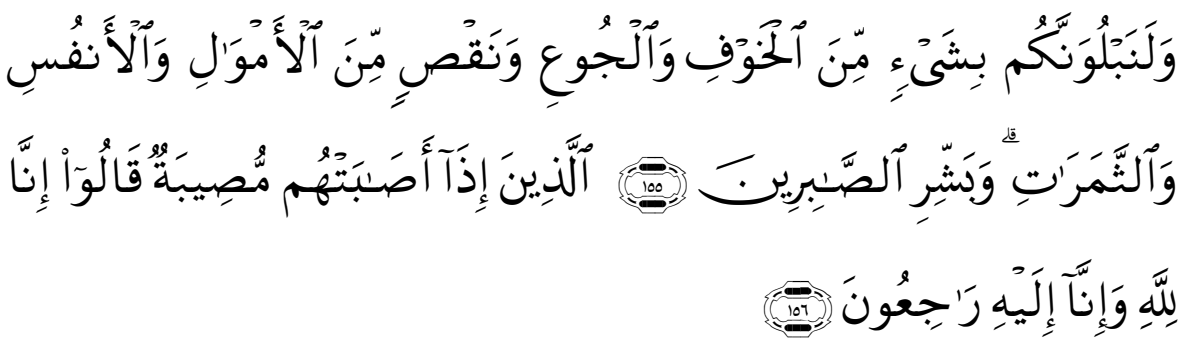

Terjemahan: dan sungguh akan Kami berikan cobaan kepadamu, dengan sedikit ketakutan, kelaparan, kekurangan harta, jiwa dan buah-buahan. dan berikanlah berita gembira kepada orang-orang yang sabar.(yaitu) orang-orang yang apabila ditimpa musibah, mereka mengucapkan: "Inna lillaahi wa innaa ilaihi raaji'uun"

Dalam ayat tersebut Allah memberikan cobaan kepada manusia berupa msibah (berupa sedikit ketakutan, kelaparan dan kekurangan harta dan jiwa), agar kita bersabar dalam menghadapinya dan bertawakkal kepada Allah. Serta merenungi dosa apa yang pernah kita perbuat hingga Allah menurunkan musibah makhluknya.

Allah Subhanahu wa Ta`ala juga berfirman (Dapertemen Agama Republik Indonesia : 2009)dalam ayat-Nya seperti dalam surat Asy-Syuuraa ayat 30.

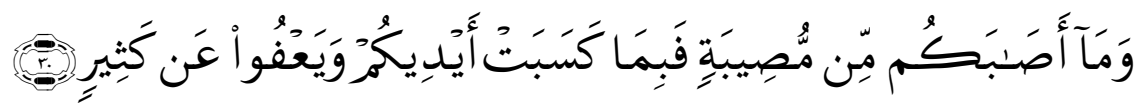

Terjemahan: dan apa saja musibah yang menimpa kamu Maka adalah disebabkan oleh perbuatan tanganmu sendiri, dan Allah memaafkan sebagian besar (dari kesalahan-kesalahanmu).

Dalam ayat ini juga Allah mengabarkan bahwa apapun musibah yang menimpadiri kita, atas dasar perbuatan tangan kita sendiri, dosa-dosa yang kita perbuat yang telah melampaui batas. Dan hanya bisa dihentikan dengan taubatan nasuha (taubat yang sungguhsungguh) agar Allah subhanahu wa Ta`ala segera menghilangkan virus ini dari muka bumi. 
Tentulah dari kita semua merindukan berkumpul dengan sanak saudara, pergi kesuatu tempat untuk melihat dan memikirkan ciptaan Allah dan pastinya kita sebagai siswa/mahasiswa merindukan sekolah/kampus, belajar bersama, berjumpa dengan guru dan teman secara langsung dan merindukan duduk dimajelis ilmu, menuntut ilmu syar $i$, berjumpa dengan sahabat dan teman satu kajian, serta mendengarkan nasihat serta ilmu yang diberikan oleh para asatidz. Banyak sekali rencana yang tertunda selama covid 19, masih ada dimuka bumi .Namun, perbanyak dzikir, beramal sholeh serta taubat yang sunggh-sungguh, agar Allah segera menghilangkan virus ini dari muka bumi.

\section{Penggunaan Aplikasi Zoom Cloud Meeting dalam Proses Pembelajaran}

Seperti yang telah dijelaskan diawal, bahwa penyebaran virus ini berdampak pada setiap tatanan kehidupan masyarakat Indonesia, misalnya tatanan ekonomi, politik, sosial budaya, ibadah bahkan berdampak sistem pendidikan. Seperti yang kita lihat saat ini pemerintah memindahkan proses belajar siswa/mahasiswa yang seharusnya tatap muka menjadi belajar dirumah. Menurut Robiah (Akhmal Annas Hasmori : 20011) sendiri, pendidikan membolehkan dalam hal berinteraksi antara individu satu dengan individu yang lain atau interaksi secara individu dengan kelompok. Al-Syaibani mengartikan, pendidikan usaha untuk mencapai baik dalam hal tingkah laku seseorang dari kepribadiannya didalam bermasyarakat dan pada kehidupan alam sekitar (Abdul Rahman : 2012). Terkait persoalan ini bahwa pendidikan merupakan usaha untuk memperbaiki akhlak dan mengembangkan potensi yang ada dalam diri seseorang agar menjadi insan yang sempurna dan mampu mengimplementasikan dalam kehidupan bermasyarakat dan alam sekitar.

Proses pembelajaran pun tak luput dari interaksi dengan orang lain. Membutuhkan guru, teman kelas dan tempat untuk mengekspresikan potensinya. Artinya manusia memerlukan manusia lain. Berbeda halnya dengan saat ini yang kita rasakan. Proses pembelajaran sedemikian rupa, jika dahulu menerapkan sistem pembelajaran konvensional, sekarang menerapkan sistem pembelajaran modern dengan konsep online. surat edaran Kementrian Pendidikan dan Kebudayaan (Kemendikbud) Direktorat Pendidikan 
Tinggi No. 1 Tahun 2020 tentang pencegahan covid 19. Didalam surat tersebut dimuat 10 poin yang salah satunya himbauan kepada seluruh jenjang pendidikan untuk melakukan pembelajaran jarak jauh (daring) dan belajar dirumah masing-masing (Zainal Abidin : 2019). Hal tersebut ditanggapi secara sigap oleh siswa/mahasiswa untuk belajar dirumah masing-masing tentu menggunakan media agar proses pembelajaran dapat berjalan dengan lancar. Sejak diberlakukannya lockdown, dimana setiap instansi ataupun lembaga sekolah atau perguruan tinggi, semua diliburkan.Namun buka sekadar libur saja, namun pekerjaan atau pembelajaran diganti dengan "belajar dirumah" ataupun "bekerja dirumah".

Akhir-akhir ini pengguna gadget disibukkan dengan salah satu aplikasi yang sangat berperan disaat masa-masa seperti ini. Aplikasi tersebut bernama zoom cloud meeting. Aplikasi ini berupa alat bantu virtual yang memudahkan manusia untuk berinteraksi dengan manusia lain. Aplikasi ini juga membantu kita agar dapat terhubung dengan orang banyak walau hanya didalam rumah.Melalui aplikasi ini juga kita dapat rapat online, belajar online dan bekerja online.Akan tetapi, tidak semuanya belajar online ini mengasyikkan bahkan sebagian peserta didik/mahasiswa berasumsi bahwa belajar online bisa sedikit agak santai.Pembelajaran media online memiliki kekurangan, diantaranya guru dan siswa tidak memiliki interaksi secara langsung.Dalam mengembangkan potensi anak, dorongan dan motivasi dari guru dan teman memiliki peran besar dalam keadaan psikologisnya. Jika berjumpa dengan guru hanya melalui media, bagaimana dengan tumbuh kembang sang anak. Demikian juga dengan metode pembelajaran yang dipilih oleh guru.

Dalam keadaan belajar secara tatap muka guru dapat memilih metode pembelajaran yang modern yang lebih asyik jika diterapkan bersama peserta didik sehingga membuat peserta didik tertarik untuk belajar dan mendalami materi tersebut.Berbeda halnya dengan pembelajaran online melalui media virtual. Guru tidak ada pilihan lain selain menggunakan metode belajar konvensional seperti ceramah dan tanya jawab sehingga mengundang kejenuhan peserta didik dalam belajar. Menurut Hakim T (Nurkholis: 2020) kejenuhan belajar adalah kondisi mental seseorang saat mengalami rasa bosan dan lelah yang amat sangat hingga menimbulkan rasa lesu dan tidak bersemangat melakukan aktivitas apapun kondisi seperti ini dapat memperhambat peserta didik dalam mencapai kematangan berpikir 
serta mencapai tujuan belajarnya secara akademis dan psikologis. Diakibatkan dari pembelajaran online yang kurang optimal, yang hanya dibebankan dengan tugas yang begitu banyak membuat peserta didik mengalami trauma secara psikologis yang mengakibatkan pembelajaran kurang efektif.

Solusi yang harus ditawarkan oleh guru yaitu membuat agar pembelajaran online menjadi lebih menyenangkan bagi peserta didik seperti guru membuat game yang dibagikan kepada peserta didik melalui media online namun game yang mengandung edukasi didalamnya. Atau guru menyediakan waktu bagi peserta didik untuk mencurahkan isi hatinya selama pembelajaran via zoom serta memberikan motivasi untuk peserta didik. Pembelajaran melalui media memang kurang efektif daripada belajar langsung dikelas. Namun ini harus tetap dilakukan selama virus corona belum hilang dan untuk memutus mata rantai penyebaran virus corona.

\section{Hambatan Pembelajaran Online}

Pada pertengahan bulan maret lalu, Kementrian Pendidikan dan Kebudayaan mengeluarkan surat edaran untuk menghimbau seluruh jenjang pendidikan untuk belajar dirumah masing-masing. Dan belajar via online hal ini membuat guru dan siswa memindahkan proses pembelajaran yang seharusnya dilakukan secara tatap muka, namun kali ini terasa berbeda karena dilakukan melalui media online. Seperti menggunakan aplikasi whatsapp group, skype, google classroom, zoom cloud meeting dan aplikasi lainnya yang relevan.

Justru hal ini membuat siswa belajar tanpa ruang artinya siswa mampu mencari informasi lain, sembari guru menjelaskan materi. Jalan ini membuat pembelajaran lebih efektif, mampu menciptakan interaksi yang lebih intensif.Namun pembelajaran ini juga memiliki hambatan. Dari hasil penelitian, 3 hambatan dalam pembelajaran via online(Dindin Jamaluddin : 2020) yaitu:

1. Kuota yang terbatas sebanyak $21,5 \%$

2. Jaringan tidak stabil sebanyak $23,4 \%$

3. Tugas yang menumpuk sebanyak $30,6 \%$

Dari ketiga hambatan tersebut harus ditindak lanjuti oleh pihak lembaga agar selama covid 19 ini masih berlangsung untuk menyiapkan solusi supaya pembelajaran masih tetap berjalan.Langkah yang penulis tawarkan yaitu menyarankan menggunakan aplikasi rendah kuota seperti E-Knows saat 
pembelajaran. Durasi penyampaian materi tidak perlu terlalu panjang, karna akan memakan kuota yang cukup banyak. Dan masalah yang paling banyak dialami oleh siswa/mahasiswa yaitu tugas yang terlalu banyak dan menumpuk. Hal ini bukan membuat siswa/mahasiswa memahami suatu materi, akan tetapi justru membuat siswa/mahasiswa stress dan trauma, hingga menyebabkan terhambatnya perkembangan siswa/mahasiswa dari aspek akademis dan psikologis. Solusinya adalah guru/dosen cukup memberikan materi singkat untuk memberikan stimulus kepada siswa/mahasiswa mengenai materi tersebut.Setelah itu ciptakan diskusi kecil melalui whatsapp group, google classroom, atau aplikasi yang lebih hemat penggunaan kuota.

\section{Kesimpulan}

Pola pendidikan yang sedikit berbeda dari sebelumnya.Tentu hal ini disebabkan karena merebaknya wabah covid 19, yang masuk ke Indonesia sejak awal maret lalu.Berdampak pada seluruh tatanan yang ada di Indonesia seperti tatanan ekonomi, politik, sosial bahkan berdampak pada sistem pendidikan. Sejak surat edaran yang dikeluarkan oleh Kementrian Pendidikan dan Kebudayaan bahwa seluruh siswa/mahasiswa untuk melakukan pembelajaran jarak jauh dengan menggunakan via online. Maka antara guru/dosen terhadap siswa/mahasiswa memerlukan jembatan agar pembelajaran tetap aktif walau ditengah pandemi. Aplikasi zoom cloud meeting, seakan-akan menjadi kelas baru dalam proses pembelajaran. Serta aplikasi ini pun menjadi solusi agar pembelajaran disekolah atau perguruan tinggi berjalan dengan semestinya .Meskipun banyaknya siswa/mahasiswa yang mengeluhkan tentang pembelajaran online.Namun ini tetap harus dilakukan hingga keadaan kembali normal. 


\section{DAFTAR PUSTAKA}

Abidin, Zainal. Rumansyah dan Kurniawan Arizona, "Pembelajaran Online berbasis Proyek Salah Satu Solusi Kegiatan Belajar Mengajar di Tengah Pandemi Covid 19” Jurnal Ilmiah Profesi Pendidikan Vol. 5 No. 1 Mei 2020

CNN Indonesia Nasional, Jokowi Umumkan Dua WNI Positif Corona Di Indonesia

Dapertemen Agama Republik Indonesia, Al-Quran Tjwid Dan Terjemahanya, Jakarta: Jabal Roudhatul Jannah

Firman dan Sari Rahayu Rahman, "Pembelajaran Online di Tengah Pandemi Covid 19" Indonesian Journal Education Sciences (IJES) Vol. 02 No. 02 Maret 2020

Hasmori,Akhmal Annas. Husin Sarju, Ismail Sabri Norihan, Rohanah

Hamzah dan Muhammad Sukri Saud, "Pendidikan, Kurikulum, dan Masyarakat: Satu Integrasi", Journal of Edupress Vol. 1 September 2011

Jamaluddin,Dindin. Teti Ratnasih, Heri Gunawan, Epa Paujiah, "Pembelajaran Daring Masa Pandemik Covid 19 Pada Calon Guru: Hambatan, Solusi dan Proyeksi", Karya Tulis Ilmiah Lembaga Peneltian dan Pengabdian Kepada Masyarakat UIN Sunan Gunung Djati Bandung 2020

Mona, Nailul. "Konsep Isolasi dalam Jaringan Sosial untuk Meminimalisasi Efek Contagious (Kasus Penyebaran Virus Corona di Indonesia), Jurnal Sosial Humaniora Terapan Vol. 2 No. 2 Januari-Juni 2020

Nurkholis, "Dampak Pandemi Novel Corona Virus Disiase (Covid 19) Terhadap Psikologi dan Pendidikan Serta Kebijakan Pemerintah” Jurnal PGSD Vol. 6 No. 1 Januari-Juni 2020 
34 Fitriyani, Marisa, Kamsi, Penggunaan Aplikasi Zoom,.....

Patunru, Arianto. Galuh Octania, dan Pingkan Audrine, "Ringkasan Kebijakan No. 3 Penanganan Gangguan Rantai Pasok Pangan di Masa Pembatasn Pandemi Covid 19" Center for Indonesian Policy Studies Mei 2020

Rahman, Abdul. "Pendidikan Agama Islam dan Pendidikan Islam Tinjauan Epistemologi dan Isi-Materi”, Jurnal EksisVol. 8 No. 1 Maret 2012

Yunus, Nur Rohim.dan Annisa Rezki, "Kebijakan Pemberlakuan Lockdown sebagai Antisipasi Penyebaran Corona Virus Covid 19",Jurnal Sosial dan Budaya Syar`i Vol. 7 No. 3 2020

Zahrotunnimah, "Langkah Taktis Pemerintah Daerah Dalam Pencegahan Virus Corona Covid 19 di Indonesia” Jurnal Sosial dan Budaya Syar`i Vol. 7 No. 32020

Zendrato,Walsyukurniat. "Gerakan Mencegah daripada Mengobati Terhadap Pandemi Covid 19, Jurnal Education and Development Vol. 8 No. 2 edisi Mei 2020 